ZOOLOGIA 30 (2): 130-134, April, 2013

http://dx.doi.org/10.1590/S1984-46702013000200002

\title{
Reproductive biology of the coypu, Myocastor coypus (Rodentia: Myocastoridae) in western Japan
}

\author{
Runami lori', Yousuke Gunji ${ }^{1}$, Mitsugu Hishinuma ${ }^{1}$, Masashi Nagano², \\ Tatsuyuki Takada ${ }^{3} \&$ Shogo Higaki ${ }^{3,4}$
}

\author{
${ }^{1}$ Department of Theriogenology, School of Veterinary Medicine, Faculty of Agriculture, Tottori University. Tottori 680-8553, \\ Japan. \\ ${ }^{2}$ Laboratory of Theriogenology, Department of Veterinary Clinical Sciences, Graduate School of Veterinary Medicine, \\ Hokkaido University. Sapporo 060-0818, Japan. \\ ${ }^{3}$ Ritsumeikan Global Innovation Research Organization, Ritsumeikan University. Nojihigashi 1-1-1, Kusatsu, \\ Shiga 525-8577, Japan. \\ ${ }^{4}$ Corresponding author. E-mail: shogohigaki@gmail.com
}

\begin{abstract}
We describe the reproductive biology of the coypu, Myocastor coypus (Molina, 1782), in western Japan, as an attempt to contribute to an efficient population control program of the coypu population. A total of 212 specimens (113 males and 99 females) were collected in the Tottori prefecture from February 2010 to January 2012. From the age estimation based on body weight and molar eruption pattern, we determined that both males and females reach sexual maturity at 4-6 months of age. Of the 72 mature females examined, 60 (83.3\%) were pregnant, with a mean litter size of $6.5 \pm 2.4$ (mean $\pm \mathrm{SE}$ ). The onset of sexual maturity in the western Japanese population was relatively earlier when compared with indigenous and other introduced populations. Furthermore, the population in Japan had relatively higher pregnancy rates and larger litter sizes, without obvious seasonal fluctuation. These observations may imply that the hunting pressure in Japan in the past 50 years has been strong enough to select individuals that mature earlier; however, nothing in the present habitat of the coypu population seems to be limiting reproduction. The relatively high reproductive potential of the present population in the mild climate of western Japan must be considered when determining appropriate management measures for this species.
\end{abstract}

KEY WORDS. Litter size; pregnancy rate; sexual maturity.

The coypu, Myocastor coypus (Molina, 1782), is a large semi-aquatic herbivorous rodent native to South America that has established feral populations worldwide, mainly as a consequence of escapes and releases from fur farms (Bounds et al. 2003, CARTER \& LeONARD 2002). In most regions, the coypu is considered a pest because it causes damage to water control structures, crops, and marsh systems (GosLInG \& BAKER 1991, REgGIANI et al. 1993) and is host to parasites that affect humans and livestock (EL-Kouba et al. 2009).

In Japan, a wild coypu population became established in the 1950s, and reports of agricultural crop damage emerged in the early 1960s (Mivra 1994). Because of the lasting effects of the agricultural crop damage caused by the coypu, the species has been hunted for eradication and control since 1963 (MIURA 1994). Although more than 50,000 animals were killed in the last 10 years (Ministry of Environment, JapAn 2011), the coypu habitat has expanded and crop damage has increased to more than $\$ 1$ million annually, mainly in western Japan (MinISTRY OF Agriculture, Forestry and Fisheries, Japan 2009).
The coypu has been successfully eradicated from a large area in England (GosuIng 1989) and two small areas in the USA. Furthermore, populations in several countries are controlled to reduce crop damage (CARTER \& LEONARD 2002). Investigations on the reproductive biology of the coypu can enhance our understanding of the population dynamics of the species, and help in the development of efficient eradication and control programs (GOSLING \& BAKER 1987). There is considerable variation in coypu reproductive parameters among populations and their habitats (ATwood 1950), and little information is available on the fecundity of the coypu in Japan. To enhance the efficiency of control or eradication efforts, our objective was to examine the reproductive biology of the coypu in the country.

\section{MATERIAL AND METHODS}

Our study was conducted in the city of Kurayoshi, Tottori prefecture $\left(35^{\circ} 30^{\prime} \mathrm{N}, 134^{\circ} 14^{\prime} \mathrm{E}\right)$, western Japan (Fig. 1). The site has a sub-tropical climate with well-defined seasons and mean 


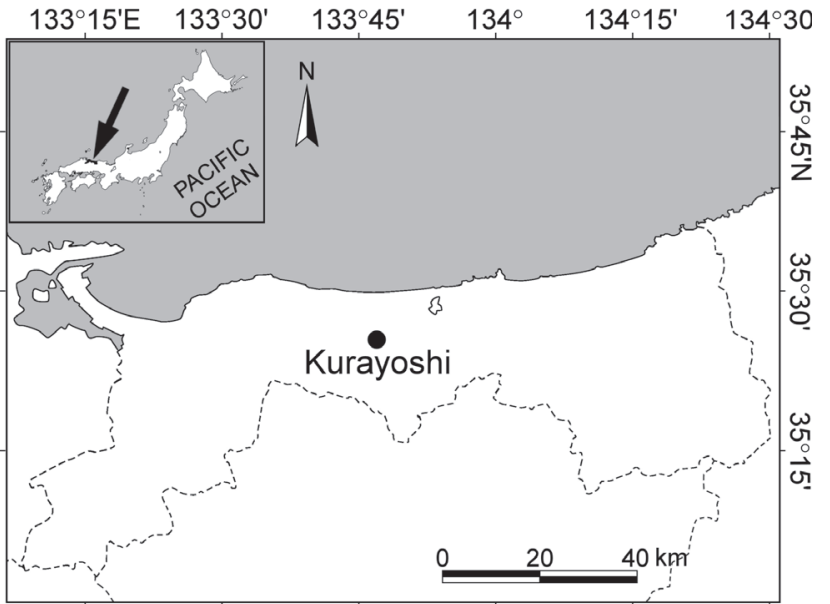

Figure 1. Location of the study area in Tottori prefecture, Japan.

winter temperatures of $5.0^{\circ} \mathrm{C}$ (December through February) and summer temperatures of $24.8^{\circ} \mathrm{C}$ (June through August). The average local annual precipitation is $1914.0 \mathrm{~mm}$, including 214 $\mathrm{cm}$ snowfall (Japan Meteorological Agency). The number of freezing temperature days, with a daily minimum temperature of $0^{\circ} \mathrm{C}$ or less and a daily maximum temperature of $5^{\circ} \mathrm{C}$ or less (GosLING 1981), is approximately 10 in a year, which are distributed.

Between February 2010 and January 2012, a total of 212 coypu were obtained from trappers during routine wildlife management activities conducted by the administration of Tottori prefecture, using cage traps. After being anesthetized with an intraperitoneal injection of $60.0 \mathrm{mg} / \mathrm{kg}$ sodium pentobarbital (Somnopentyl, Kyoritsu Seiyaku Co., Tokyo, Japan), all animals were euthanized with an intracardiac injection of $150.0 \mathrm{mg} / \mathrm{kg}$ potassium chloride and transported to the laboratory. We determined the sex of each coypu according to the external genitalia as described previously (Bounds et al. 2003), and recorded the body weight to the nearest $50 \mathrm{~g}$.

The entire reproductive tract of each coypu was dissected out and examined. The reproductive activity of males was assessed by microscopic examination of a smear taken from the freshly cut surface of the cauda epididymis. If copious amounts of sperm were present in the smear, the coypu was considered sexually mature (WILLNER et al. 1979).

The reproductive activity of females was determined on the basis of a macroscopic examination of the uterus and ovaries. Each uterus was opened and examined for the presence of fetuses. Each ovary was cut with a scalpel into longitudinal sections. If a well-developed corpus luteum $(>0.5 \mathrm{~mm}$ in diameter) and/or follicles ( $>2.0 \mathrm{~mm}$ in diameter) were present in the ovaries, the coypu was considered sexually mature (Felipe et al. 1999, 2000). Hence, three reproductive statuses were distinguished in females: 1 ) mature pregnant females with a well developed corpus luteum and/or follicles, 2) mature non-pregnant females with a well developed corpus luteum and/or follicles, and 3) immature females with no sign of reproductive activity. When a female was pregnant, the number of fetuses was recorded.

The age of each coypu was estimated using two methods: body weight (SHERFy et al. 2006), and sequential molar eruption (MiURA 1977). In brief, the age of each coypu was estimated using body weight with the following model (SHERFY et al. 2006): $W t=A \times \exp \left(-e^{-b(t-k)}\right)$; where $W t$ is the body weight (grams) for age $t$ (number of months), $A$ is the asymptotic value of body weight (6163.2 for males and 5382.2 for females), $e$ is the base of natural logarithms (2.718), $k$ is the value of the dependent variable at the point of maximum growth rate (6.429 for males and 5.382 for females), and $b$ is the growth-rate parameter (0.152 for males and 0.178 for females).

Based on the sequential eruption of the right mandibular molar, animals were grouped into the following four dental age classes (I-IV) and their age was estimated according to the criteria described in a previous report (MiURA 1977): dental age class I, incomplete eruption of the first molar ( $<2$ months old); dental age class II, complete eruption of the first molar and incomplete eruption of the second molar (2-6 months old); dental age class III, complete eruption of the second molar and incomplete eruption of the third molar (6-14 months old); dental age class IV, complete eruption of the third molar $(\geqslant 4$ months old).

Seasonal variation in the proportion of pregnant females and litter size was examined using the Fisher's exact test (twotailed) and the Kruskal-Wallis analysis, respectively. The Fisher's exact test was performed using a web-based program available at http://in-silico.net/statistics. Kruskal-Wallis analysis was performed using the program SPSS for Windows, Version 12.0, SPSS Inc., IL, USA.

\section{RESULTS}

Of the 113 males examined, 78 were classified as mature (Fig. 2). The weight of the smallest male animal classified as mature was $1.50 \mathrm{~kg}$ and its dental age class was II; according to the body weight and dental age class, this animal was estimated to be about four months old. All males weighing $\geqslant 2.15 \mathrm{~kg}$ were classified as mature and their dental age classes were III or IV. These animals were estimated to be older than six months.

Of the 99 females examined, 72 were classified as mature; 58 of them were pregnant [overall pregnancy rate was $83.3 \%(60 / 72)$ ] and 14 were not pregnant but had a well-developed corpus luteum and/or follicles (Fig. 3). The weight of the smallest female animal classified as mature was $1.75 \mathrm{~kg}$ and its dental age class was II; the animal was estimated to be about four months old. All females weighing $\geqslant 2.50 \mathrm{~kg}$ were mature and their dental age classes were III or IV. These animals were estimated to be older than six months. 

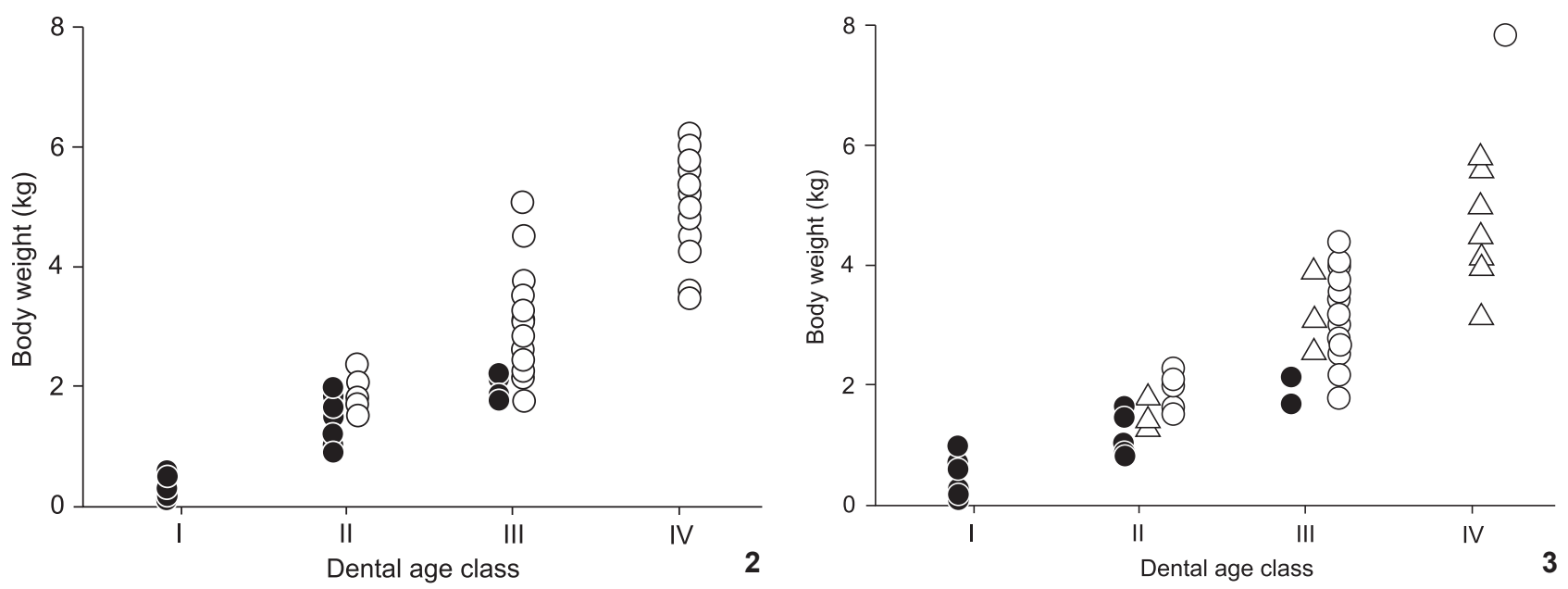

Figures 2-3. Relationship between sexual maturity and body weight/dental age class in coypu in western Japan. (2) Males: animals with $(O ; n=78)$ and without $(0 ; n=35)$ copious amounts of sperm in the smear taken from the freshly cut surface of the cauda epididymis; (3) Females: pregnant animals $(O ; n=58)$ and non-pregnant animals with $(\triangle ; n=14)$ and without $(\bullet ; n=27)$ well-developed corpus luteum ( $>0.5 \mathrm{~mm}$ in diameter) and/or follicle(s) (>2.0 mm in diameter). Dental age class I: incomplete eruption of the first molar; dental age class II: complete eruption of the first molar and incomplete eruption of the second molar; dental age class III: complete eruption of the second molar and incomplete eruption of the third molar; dental age class IV: complete eruption of the third molar

Seasonal variation was not detected in the proportion of pregnant females or in litter size $(\mathrm{p}=0.2597$ and 0.096 , respectively) (Fig. 4). The overall mean litter size was $6.5 \pm 2.4$ (mean \pm SE) with a range of 1-12 fetus(es) per pregnant female.

\section{DISCUSSION}

Our results show that, in western Japan, the coypu may reach sexual maturity at 4-6 months of age, regardless of sex, similar to the age of maturity of other introduced populations in the USA (Atwood 1950, Willner et al. 1979), England (GosLING 1974, Laurie 1946, Newson 1966), and Italy (Сocchi \& RigA 2008), and less than that of indigenous population in Argentina (males: 8-11 months; females: 5-10 months) (GUicHón et al. 2003). Purvis et al. (2001) suggested that sustainable harvesting of wildlife populations should exert a strong selective force for earlier maturity. Approximately 50 years of hunting pressure on the present population (MIURA 1994) may have induced the coypu's rapid growth to sexual maturity in western Japan, as observed in other introduced populations.

We observed the presence of pregnant females throughout the year, confirming that the coypu is a non-seasonal breeder, as reported for indigenous and other introduced populations (AdAms JR 1956, GosLing 1974, Linscombe et al. 1981, NEWSON 1966, Willner et al. 1979). The overall pregnancy rate of the present population (83.3\%) was higher than that of the population in Maryland (64.9\%) (WILLNER et al. 1979) and similar to the pregnancy rates of populations in other parts of the USA (approximately 80-100\%) (ADAMS JR 1956, ATwood 1950,

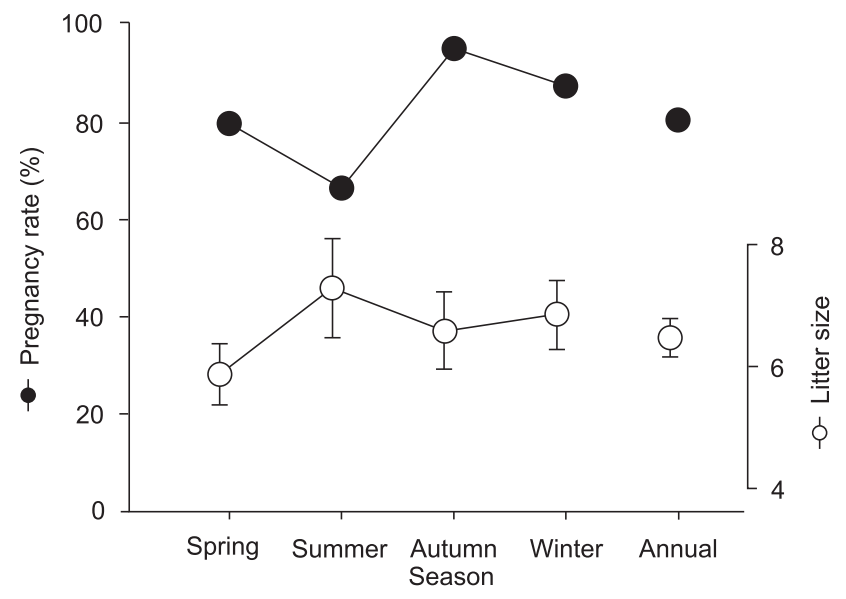

Figure 4. Seasonal variation in the proportion of pregnant females within the matured females $(\bullet ; n=20,15,21$, and 16 of matured females in spring, summer, autumn, and winter, respectively) and litter size $(O ; n=16,10,20$, and 14 of pregnant females in spring, summer, autumn, and winter, respectively) in coypu from western Japan. Spring, summer, autumn, and winter: March through May, June through August, September through November and December through February, respectively. Values for litter size are expressed as mean $\pm \mathrm{SE}$.

Evans 1970, Linscombe et al. 1981). Although KiLner et al. (1987) reported seasonal fluctuation of the pregnancy rate in the Louisiana population, ranging from 58\% in May to $100 \%$ in Febru- 
ary, no obvious seasonal variation was evident in the population of Kurayoshi. This discrepancy may result from the plentiful food resources throughout the year in western Japan, owing to the fewer days when the temperature is below freezing. Because roots and rhizomes, the primary winter food supply of the coypu (EluIs 1963, GosLing 1974), are relatively inaccessible when the ground is frozen, freezing temperatures may result in depleted fat reserves, a condition directly linked with reproductive failure (GosLING 1981).

The present population showed a relatively large mean litter size (6.5) compared with mean litter size obtained from other introduced populations (4.0-6.0) (ADAMs JR 1956, BRown 1975, Gosling 1986, Linscombe et al. 1981, Newson 1966, Willner et al. 1979). The larger mean litter size observed in the present study may be partly because of the absence of a drop in litter size during winter, as observed in populations from the USA (Willner et al. 1979) and England (Newson 1966). The lower mean litter size during winter may result from high fetal mortality, as suggested previously (GosLING 1981), and the larger litter size we observed suggests that the winter cold in the present study area was too mild to cause fetal death.

Cold weather is an effective factor limiting coypu reproduction (Newson 1966, Reggiani et al. 1995, Willner et al. 1979) and helps eradication (GOSLING \& BAKER 1989). Unfortunately, the present results may indicate that the winters of western Japan are too mild to limit coypu reproduction. BRown (1975) suggested that adult females may produce two or more litters per year (mean $=2.7$ ) in areas with mild climate and plentiful food. In the present study area, this would represent a total maximum reproductive potential, which would be approximately 17.6 (6.5 $\times 2.7$ ) young per adult female per year, assuming no brood was lost. The high reproductive potential resulting from lack of seasonal fluctuation in the pregnancy rate and litter size of the present population must be considered when determining appropriate management measures for this species in Japan.

\section{ACKNOWLEDGMENT}

We would like to thank Hideki Nishimura for generously supplying coypu samples.

\section{LITERATURE CITED}

Adams JR, W.H. 1956. The nutria in coastal Louisisana. Proceedings of the Louisiana Academy of Sciences 19: 28-41.

Aтwood, E.L. 1950. Life history studies of nutria, or coypu, in coastal Louisiana. The Journal of Wildlife Management 14: 249-265.

Bounds, D.; M. Sherfy \& T. MOlletT. 2003. Nutria, p. 1119-1147. In: G.A. Feldhamer, B.C. Thompson, and J.A. Chapman (Eds). Wild mammals of North America. Baltimore, Johns Hopkins University, VII+1368p.
BRown, L.N. 1975. Ecological relationships and breeding biology of the nutria (Myocastor coypus) in the Tampa, Florida, area. Journal of Mammalogy 56: 928-930.

Carter, J. \& B. Leonard. 2002. A review of the literature on the worldwide distribution, spread of, and efforts to eradicate the coypu (Myocastor coypus). Wildlife Society Bulletin 30: 162-175.

Cocchi, R. \& F. Riga. 2008. Control of a coypu Myocastor coypus population in northern Italy and management implications. Italian Journal of Zoology 75: 37-42.

El-Kouba, M.M.A.N.; S.M.T. Marques; C. Pilati \& W. Hamann. 2009. Presence of fasciola hepatica in feral nutria (Myocastor coypus) living in a public park in Brazil. Journal of Zoo and Wildlife Medicine 40: 103-106.

ELLIS, E. 1963. Some effects of selective feeding by the coypu Myocastor coypus on the vegetation of Broadland. Transactions of the Norfolk and Norwich Naturalists' Society 20: 32-35.

Evans, J. 1970. About nutria and their control. United States Bureau of Sport Fisheries and Wildlife 86: 1-65.

Felipe, A.; J. Cabodevila \& S. Callejas. 1999. Anatomicohistological characteristics of the ovary of the coypu (Myocastor coypus). Anatomia, Histologia, Embryologia 28: 89-96.

Felipe, A.; M. Teruel, J. Cabodevila \& S. Callejas. 2000. Typological series for ovarian follicles of sexually mature Myocastor coypus (coypu). Biocell 24: 97-106.

GosLING, L. 1974. The coypu in East Anglia. Transactions of the Norfolk and Norwich Naturalists' Society 23: 49-59.

GosLING, L. 1981. Climatic determinants of spring littering by feral coypus, Myocastor coypus. Journal of Zoology 195: 281288.

GosLING, L. 1986. Selective abortion of entire litters in the coypu: adaptive control of offspring production in relation to quality and sex. The American Naturalist 127: 772-795.

GosLing, L. \& S. BAKER. 1987. Planning and monitoring an attempt to eradicate coypus from Britain. Symposia of the Zoological Society of London 58: 99-114.

GosLING, L. \& S. BAKER. 1989. The eradication of muskrats and coypus from Britain. Biological Journal of the Linnean Society 38: 39-51.

Gosling, L. \& S. BAKER. 1991. Coypu Myocastor coypus, p. 267275. In: S. HarRis (Ed.). Handbook of British Mammals. Oxford, Blackwell Science Inc, VI+602p.

Gosuing, M. 1989. Extinction to order. New scientist 121: 4451.

Guichón, M.; C. Doncaster \& M. Cassini. 2003. Population structure of coypus (Myocastor coypus) in their region of origin and comparison with introduced populations. Journal of Zoology 261: 265-272.

Kilner, N.W.; G. Linscombe \& P.R. Pamsey. 1987. Nutria, p. 326-343. In: M. NovaK; J.A. BaKer; M.E. Obbard \& B. Malloch (Eds). Wild furbearer management and conservation in North America Toronto, Canada. Ontario, The Ontario Trappers Association, Ontario Ministry of Natural Resources, XVIII+1150p. 
LaURIE, E. 1946. The coypu (Myocastor coypus) in Great Britain. Journal of Animal Ecology 15: 22-34.

LinsCOMBE, G.; N. Kinler \& V. WRight. 1981. Nutria population density and vegetative changes in brackish marsh in coastal Louisiana, p. 129-141. In: J.A. Chapman \& D. Pursley (Eds). Worldwide Furbearers Conference Proceedings. Portland, Unipub, 2056p.

Ministry of Agriculture, Forestry and Fisheries, Japan. 2009. Zennkoku no Yasei Choujyuu ni yoru Nousakumotsu Higai Jyoukyou ni tsuite [Report of the Wildlife Damage in the Agriculture]. Available online at: http://www.maff.go.jp/ j/press/seisan/saigai/120110.html [Accessed: 03/III/2012].

Ministry of ENVIRONMENT, JAPAN. Wild birds and mammals' statistics. Available online at: http://www.sizenken.biodic.go.jp/wildbird/ flash/toukei/07toukei.html [Accessed: 24/XI/2011].

MiURA, S. 1977. Age determination techniques for terrestrial mammals with special reference to the nutria. Mammal Science 34: 43-53.

Miura, S. 1994. Nutira, p. 539-546. In: Japanese Fishing Agency (Ed.). Nihon no Kishou na Yasei Suisei Seibutsu ni kansuru Kiso Shiryo [Basic data on rare wild aquatic organisms in Japan]. Tokyo, Japan Fisheries Resource Conservation Association. IV+446p.

Submitted: 27.VII.2012; Accepted: 21.IX.2012

Editorial responsibility: Fernando de C. Passos
Newson, R.M. 1966. Reproduction in the feral coypu (Myocastor coypus). Symposium of Zoology Society of London 15: 323334.

Purvis, A.; J. Reynolds; G. Mace; K. Redford \& J. Robinson. 2001. Mammalian life histories and responses of populations to exploitation, p. 169-181. In: J.D. REYNoLDS (Ed.). Conservation of exploited species. Cambridge, Cambridge University Press, XXVII+524p.

Reggiani, G.; L. Boitani; S. D'antoni \& R. De Stefano. 1993. Biology and control of the coypu in the Mediterranean area. Supplementi alle Ricerche di Biologia della Selvaggina 21: 67-100.

Reggiani, G.; L. Boitani \& R. Stefano. 1995. Population dynamics and regulation in the coypu Myocastor coypus in central Italy. Ecography 18: 138-146.

Sherfy, M.; T. Mollett; K. McGowan \& S. Daugherty. 2006. A reexamination of age-related variation in body weight and morphometry of Maryland Nutria. Journal of Wildlife Management 70: 1132-1141.

Willner, G.R.; J.A. Chapman \& D. Pursley. 1979. Reproduction, physiological responses, food habits, and abundance of nutria on Maryland marshes. Wildlife Monographs 65: 3-43. 